\title{
What if they don't want your kind of development? Reflections on the Southern Highlands
}

\section{Maev O'Collins}

In his entry for the Southern Highlands in the Encyclopaedia of Papua New Guinea, McAlpine (1972:1089) noted that:

The bellicosity of precontact society was indicated by the fighting ditches and trenched roads lined with defensive gate barriers noted by early exploratory patrols.... The District was the last to be brought into contact with European society and partly as a consequence is one of the least developed heavily populated areas....Isolation and the recency of pacification have delayed economic and social development.

After the major exploratory patrol by J.G. Hides and L.J. O'Malley in 1935, the Southern Highlands remained relatively undisturbed until after World War II, with increased Australian administrative contact gathering momentum only in the 1950s and early 1960s. McAlpine described the task as 'virtually completed by $1965^{\prime}$ and considered that: 'Despite the penchant for intertribal warfare pacification was remarkably peaceful' (ibid). Nevertheless, as French and Walter reminded their readers (1984:20):

It was not until the early 1970s, however, when the last isolated groups were located and the Hewa area north of Kopiago was derestricted (in 1973), that this phase was completed province-wide.

\section{First contacts on the road to independence}

When I commenced teaching at the University of Papua New Guinea in 1972, Southern Highland students in my classes provided vivid first-hand accounts of the first Australian patrols that had come to their scattered communities. Schools had been established and they had gone on to high school and now, in their mid 20s, they were to become the first university graduates from their areas. Self-government was a reality and independence was on the horizon. This was both an exciting and a daunting prospect, as it was expected that these new graduates would assist their people to 'catch up' with the more developed areas of Papua New Guinea.

At the same time, it was clear that the Australian colonial system of government and administration, which was now to be handed over to a national government, had not yet been fully understood or accepted. The inherent 
difficulties in taking on responsibility for economic and social development activities and projects were also appreciated, and students began to question the wisdom of imposing a preordained form of development on their people.

At a seminar in 1973 a group of students, who had spent several weeks in Wambip, a village in what is now the Karint sub-division of the Mendi District (see Bourke et al 1995), reported on their findings (Bais et al 1973). After a lively discussion as to whether silk worms, citrus, cattle, coffee or other projects could, or should, be established, one Southern Highlander challenged me as the only Australian present.

What happens if they don't want your kind of development? What do we do if they want to go back to the way things were before you people came and disturbed their lives?

The students' field experience had been further enlivened by differences of historical record on what had happened in the early1950s when the first Australian-led patrol had come into the area. The older villagers recalled with great detail how the patrol had crossed their 'fight ground' so their group attacked, as they knew these were hostile enemies. But the patrol retaliated with gunfire and six or eight had died. The men pointed to the places on the nearby hillside where a father or uncle had fallen. Although they had heard about earlier patrols, this was the reality of the new system of administrative control.

On the other hand, the Australian administrative officers in Mendi were outraged that the students had reported this story so uncritically. The official patrol reports they held told a very different story. 'The patrol had been attacked when it was peacefully crossing an open area. The numbers of dead were greatly exaggerated. The villagers had wanted to impress the students with this story'. I had to work hard to gain official approval for further student fieldwork in the Southern Highlands. All involved in the debate seemed unaware or unable to accept that both stories could be true. The villagers felt they had indeed been 'pacified' and the patrol officer's record indicated that his men had come under unprovoked attack and that they had to defend themselves.

Similar questions were raised a few months later, when I taught a long-vacation 'Working with Communities' course for high school teachers and administrative officers. The opening community development theme was:

Start where the people are. Go at their pace. Learn what they want and try to help them achieve these economic or social goals.

Nice sentiments but reality was a very different matter. One exasperated teacher responded:

I am the first person from my area to be a teacher. They think I have become a woman as I am twenty-six and I have not killed anyone. A 
strong man is someone who has killed a member of the enemy group. In the past a really strong man would have killed a policeman. What does your community development say to that?

The lessons from these stories are both in the time-scale and in the responses to external intrusion and control. My students were trying to consider the appropriate action to take to bring about effective development in some communities whose experiences of outside administrative control had begun less than twenty years earlier. I was again reminded of this in September 1975, when pictures appeared in the Post-Courier and on television of Australian patrol officers raising the Papua New Guinea flag in remote Southern Highlands patrol posts, while local community leaders looked on.

Achieving development may be a slow and painstaking process, which requires more than one generation from the first contact and many changes in strategies to achieve real and lasting success. Another question, which was frequently asked at this time, was: 'Development for whom?' One response was: 'If they don't want the suggested development, we should leave them alone.' But, as became even clearer over the next few years, it was not possible to leave them alone. In any case, most Southern Highlanders wanted to gain access to economic opportunities and the main problem was their unrealistic expectations of the overall benefits which they thought would be obtained from particular projects.

\section{The new provincial administration: 1975-1984}

In the first year or so after Papua New Guinea became an independent nation state, there was relatively little change in the administration of the Southern Highlands but a number of social development activities were initiated. The Papua New Guinea Institute of Medical Research had established a pneumonia research unit, based in Tari, and government-sponsored literacy and other non-formal education training programmes were initiated - often in cooperation with church groups, and staff and students from the University of Papua New Guinea.

At the same time, the debate over whether and when to introduce provincial government quickened, with arguments and counter-arguments as to whether this would make government more understandable and accessible, and encourage economic development (see May et al 1997). Unrealistic expectations that 'more power to the people' would automatically be achieved were countered by dire warnings that the dearth of administrative skills and experience at district and sub-district level would make it an unworkable and costly exercise. Noting these conflicting arguments, Conyers (1976:74) concluded:

The history of decentralisation in general, and the establishment of provincial government in particular, demonstrates very clearly the 
conflicting forces of centralisation and decentralisation which are in operation in the country... it is perhaps particularly evident in contemporary Papua New Guinea because of the contrast between the exceptionally decentralised traditional organisational structure and the relatively centralised system introduced by the Australian administration. This is not something that can be solved overnight by a single political or administrative reform and, although the decision to establish provincial governments has finally been made, the conflict will undoubtedly continue in Papua New Guinea for many years to come.

On one occasion, during this period of administrative confusion and transition, I visited Pangia to discuss a student fieldwork project with community leaders, administrative officers and the student involved. Heavy rain made it impossible for me to go out to the student's village, so I spent a few days with the district officer in his official residence until the vehicle from Mendi could get through.

Already the downturn in funds and qualified staff to undertake repairs and maintenance was in evidence. The indoor toilets had broken and there were no replacement valves so hastily built pit latrines were being used. The Milne Bay government officer who was my host had completed a course at the Administrative College in Port Moresby and remarked that his training had not prepared him for the experience of being held hostage by a secessionist group on Bougainville in 1975. He was suffering from a severe eye infection, which the aid post orderly was treating with very out-of-date ointment, but this did not and could not prevent him from continuing to carry out his role as the symbol of government authority in the area. Some young men had vandalised a government house. A local village woman was in a severely delusional state and had to be restrained to avoid violence to herself or her children. And, braving the muddy road, an intrepid researcher had dropped in a number of questionnaires on local contraceptive practices, with an urgent request that these be completed immediately.

I was very impressed by the imaginative and committed way in which this recently appointed district officer approached the problems and resource limitations he experienced on a daily basis. Discussions with community leaders were needed to try to resolve the incipient but worrying signs of a breakdown in traditional authority. Emergency transport had to be quickly found to take the village woman and her concerned relatives into the Mendi hospital. However, the request for him to carry out a survey of contraceptive methods was more problematic. He had just begun to feel accepted by the local leaders and did not want to do anything that would jeopardise their cooperation and trust. At the same time, his superiors expected that he would respond positively to requests from outsiders, particularly expatriate outsiders, as their favourable reports would be helpful when dealing with the central administration in Port Moresby. 
Finally, he decided that, as he was confident he knew about traditional practices in the area, he would just complete all the questionnaires himself and send them back.

Returning to the University of Papua New Guinea, with a very favourable opinion of the way this officer approached different challenges and his overall responsibilities, I quickly discovered that my positive impression was not universal. Some researchers had felt that he had not taken sufficient time to assist them, that he was a bit 'sloppy' with required paper work, and that things were not nearly as efficient as in the 'good old days' before independence.

Clearly, some of the difficulties he encountered were related to diminished resources and back-up administrative support, and to a lack of clarity as to who had ultimate administrative responsibility. In 1978, after a World Bank team visited the Southern Highlands, it recommended that a massive injection of funds would be needed to address the reality that this was one of the poorest and least developed areas they had encountered (World Bank 1978). Following this report the Southern Highlands Rural Development Project (SHRDP) was initiated, with the aim of linking economic, social and infrastructural projects to achieve more rapid and sustainable development in the province. This was during the period when provincial government was being introduced, but Southern Highlands did not yet have full financial autonomy (Regan 1997). In hindsight at least, it is not surprising that confusion often arose as to which particular administrative functions or project activities were under the ultimate authority of provincial officials, and which functions were the responsibility of the SHRDP (see Hinchliffe and Ilave 1984:66-68).

At the same time, law and order problems associated with the lack of economic opportunities for young people had heightened a general feeling throughout Papua New Guinea that the perceived breakdown in family and community authority required more organised and measured government intervention. After lengthy consultations and some political and community indecision, a National Youth Movement Program (NYMP) was established in 1980. Although there was some misgiving that this was an artificial and 'foreign' solution to community tensions, it was clear that the programme would be attractive to Australia, New Zealand and other bilateral aid donors.

An important element was that the gradual firming of government support for some kind of national youth activity took place at a time when many church and voluntary youth organisations were attempting to review their own involvement in order to reflect political and economic changes in the wider society. Whatever their own attitudes might have been, some politicians, or aspiring politicians, recognised that young people and older supporters were a political power base and supported demands for recognition by youth groups and community activists.... 
Fears that more extreme 'law and order' approaches would prevail if the National Youth Movement Program were defeated may also explain the rapidity of its final introduction (O'Collins 1984:19).

\section{Youth and their communities in the Southern Highlands}

In December 1980, the Southern Highlands was one of fifteen provinces with Provincial Youth Councils, which received initial grants of K10,000 to initiate the NYMP in the province. By May 1981, thirty-eight groups had been registered, and further government grants were received to enable recruitment of community youth coordinators.

By July 1983, 250 groups had been registered with the Provincial Youth Council and were involved with a wide variety of activities. These were a mix of economic, educational, social, sporting and religious activities, reflecting the life of young people and their communities. Nevertheless, the stated emphasis on, and the time spent undertaking, economic activities were particularly emphasised in reports sent to the National Office of the NYMP, and its international funding agencies (see O'Connell and Zarriga 1991 for an outline of the development and implementation of the NYMP).

In 1983/1984, as part of a sample survey of three provinces (Manus, Morobe and Southern Highlands), I coordinated a survey by students and youth workers on 'youth in groups' in the Southern Highlands. The purpose of this survey was to learn why groups were formed, and their sponsors, problems, activities and ways of raising finances. It quickly became apparent that the groups being surveyed had become very sophisticated in their approach to outside researchers, and that some earlier surveys had reported a much higher percentage of time spent on direct economic activities than we found to be the case. At the same time, it was unwise to disregard the economic impact and benefit of what might be categorised as 'social development' activities. This was because:

A social event to raise funds for sports equipment or a church hall; house-building by a youth group for a village leader; sports days with cash prizes to be won, are complex activities which may involve all the community, not just youth or women's groups. But, if government intervention is seen only in terms of economic development, informants considered it inappropriate to emphasise other aspects of community life (O'Collins 1984:74).

It was also beginning to be of concern to the NYMP Headquarters officials that, after receiving a small 'seed grant', many youth groups seemed to flourish for a time and then ceased to function. However, the NYMP was now receiving major funding from Australia, and an extraordinarily complex system of reporting had been instituted, so most national or provincial youth officers were reluctant to question, or to report on, what was really happening. During this same period, 
the SHRDP was involved in parallel community activities, sometimes in cooperation, but often in competition with the NYMP and other national government services. There was also a feeling among many Southern Highlanders whom I met that the involvement of expatriates as expert development specialists in both projects seemed to be continuing the same style of benevolent colonial interaction that they had experienced before independence.

On one occasion, when the promised government transport was suddenly unavailable, the Mendi-based provincial youth officer suggested that, as I was an expatriate, the chances of 'borrowing' SHRDP transport was commensurately greater than if he were to make the approach. He was quite correct in this assessment, and we spent a very productive few days visiting more distant youth groups and gathering helpful hints from the government driver. On one occasion, when we were unable to locate a particular youth group, he remarked it had ceased operations under that name and was now known by another name, which was also on our list. With this new name and a slightly changed executive it had been able to obtain another start-up grant. It became obvious that these youth groups were often really community groups, and, in the same way as with earlier nutrition or informal education projects, they provided spin-off benefits to the wider community.

Older members of the community viewed with alarm the single-minded focus on 'youth', as there was a danger that the unequal benefits going to one section of the community would be divisive. One way of avoiding a concomitant breakdown in traditional authority was to rein in the power of local youth group 'leaders' and to ensure that older members of the community accompanied youth groups attending district or provincial meetings. At the same time, as was the case with other economic resources, all members of the community often benefited from the NYMP funding of 'youth' activities.

Participation of older community members in youth group activities was noticeable in most of the rural communities which I visited in Mendi district. Older men were building community centres and constructing playing fields, younger men cleaned the roads as part of a council contract and women worked on garden projects. The Youth Office staff and local youth workers pointed out that these were activities where older people had control over the management of resources (O'Collins 1984:74).

By 1983, the Southern Highlands Provincial Youth council had funded fifty-one projects, with the majority (forty-two) categorised as economic projects. At the same time, there had been considerable criticism from NYMP Headquarters staff that there had been 'interference' from Non-Formal Education, as the aim was to amalgamate extension activities in a more orderly fashion. I had been impressed by the provincial youth officer's commitment and understanding of the needs of youth working within their own communities. Yet, he was clearly 
more comfortable in his role as an adviser and resource link for youth groups than when required to complete the lengthy formal quarterly reports required by NYMP Headquarters. So it came as no surprise to read a statement in the Second NYMP Grants Scheme Implementation Report (Office of Youth, Women, Religion and Recreation 1983:14) that the Southern Highlands Provincial Youth Office (presumably the provincial youth officer) needed to improve its general management of the NYMP. I was more surprised to read that 'transport was not a problem'.

\section{Youth projects in the Southern Highlands: Success or failure?}

By July 1983, when our survey commenced, approximately 250 youth groups were registered with the Provincial Youth Council, and although many success stories were reported other groups were inactive, or had collapsed after a period of intense and somewhat frenetic activity. An initial student fieldwork report suggested that a youth group at Umbimi (a village in the Kambiri Division of the Mendi District), was an example of the sustained economic and social benefits which could be achieved through external financial assistance (O'Collins 1984: 75-76).

This group was registered in 1982 with the Provincial Youth Council. It was described as having an initial membership of twenty, a savings bank passbook and a constitution (Kombeson 1983). Office bearers included employed members of the extended family, which was the basis of group membership. They planned to start with a number of small projects, obtain a substantial grant or loan, and establish a large chicken and piggery project (personal communication by group members).

When I visited Mendi in July 1983 the group was at a peak of successful activities. A volley ball court had been levelled and male and female teenagers participated in sports days. Plans were underway to build a church, a trade store was in operation, fully grown chickens were ready for sale, and ducks, pigeons, and a gardening project were other ongoing activities. The community youth worker (also a group member) and an older clan spokesman were confident that the group would succeed and spoke of obtaining further finance and expanding their level of economic activity. I revisited this youth group in April 1984 and found that most of the activities had ceased after the chickens had been sold. The K400 obtained from the sale had gone to purchase a second-hand truck which shortly afterwards broke down and was abandoned. There had been difficulties in finding markets for the ducks, the volley ball was destroyed in a dispute and, although a number of minor activities were being carried on, the level of enthusiasm and youth involvement had diminished. The president of the group was said to be in Port Moresby and there was a feeling of marking 
time, waiting for the next development project when perhaps enthusiasm would rekindle and activities would recommence.

In hindsight it is hard to decide whether this project had been a failure or whether the spin-off benefits for those who participated made it a success. It was clear that when the opportunity arose to gain external financial assistance, older members of the community were able to quickly mobilise the youth to meet the conditions of the NYMP Grants Scheme. But younger members of the community had also gained valuable experience, which would be useful in negotiations with external development agencies and in the management of future economic activities.

The very centralised youth-centric focus of the NYMP could also be seen as both its strength and its weakness. I had been concerned that there was a lack of flexibility; the 'one-size-fits-all' policies and implementation guidelines did not meet the different development needs, community relationships, and levels of management skill throughout the country. However, this was not the view of NYMP senior staff, who saw the subsequent decline of the NYMP as due mainly to pressures towards decentralisation and political interference:

As the central directing and co-ordinating unit became weaker, the national and nationalistic themes running through the youth programs lost their impact. Provincial procedures and identities became stronger. By the end of 1989, the National Youth Movement was financially weakened and showed clear signs of fragmenting. Youth program operations were subject to ministerial intervention on a scale considered unacceptable by the designers of the NYMP and earlier governments (O'Connell and Zarriga 1991:240).

At the same time, they (ibid:241) concluded that:

Centralised direction, quality control, and performance monitoring of accountability standards are not inconsistent with decentralised decision-making, locally negotiated working relations amongst legitimate but competing power structures, and responsiveness to grass roots needs. On the contrary, this mixture makes for a powerful and efficient development process, much more effective than the usual alternative models of constipatory centralism and dogmatic functionalism ('let the managers manage' $)$.

\section{The Lake Kutubu Project: 'What sort of development is this?'}

In June 1989, accompanied by my sister Dympna, and the wife of a UPNG colleague, I spent several days in the Lake Kutubu area. We flew from Port Moresby to Pimaga, and, after a night in the local guest house, walked along 
the track to Lake Kutubu. There a motorised canoe took us to the more established guest lodge, which had developed a programme for short-stay tourists. After a few days visiting nearby villages, we returned the same way. Apart from a young schoolboy who walked with us along the track, we had no other guides, relying upon advice from local villagers who warmly welcomed us along the way.

Large helicopters were constantly flying overhead, transporting heavy equipment to the site of the future Lake Kutubu Joint Venture oil pipeline development. The task of identifying villagers who would be impacted by the development was already well underway. We met several members of the community survey team who were engaged in recording groups with a possible claim for compensation or future royalties. The track from Pimaga to Lake Kutubu took us through Foi land. It was clear that many villagers were deeply suspicious of this impending development, while others had very unreal expectations of the financial windfalls they would receive.

Walking back towards Pimaga, we stopped at a small village near the Mubi River. After a long negotiation to persuade the owner to accept a few kina for this old and seemingly quite valueless item, Dympna acquired a 'working' canoe paddle from a village elder. During the discussions, it became clear that we had had several enjoyable and informative encounters throughout our journey, and this struck a chord with our audience. A spokesman who had completed some years at high school made a lengthy statement in Tok Pisin about how they saw the future, and the positive and negative impacts of the oil exploration, the planned pipeline developments, and the possible payment of royalties. He pointed out that once the track we had walked on was upgraded into a vehicular road, jobs would be available, money more plentiful, people would become greedy, and conflict would be inevitable:

Everything will soon change. Raskols will come and beer will be easier to get. It will not be possible for old white women like you to walk safely through our area without armed guards. We will have to fight outsiders to protect our communities and we may even begin fighting each other. People say that those helicopters will bring us development but what will it cost? What sort of development is this?

There were other clouds on the horizon. Both the small guesthouse at Pimaga and the larger and more substantial guesthouse on Lake Kutubu had been managed by volunteers. The aim was to train suitable locals to take over and to develop appropriate economic tourist activities. However, access to necessary supplies, and booking and banking facilities were needed to provide the level of food and accommodation needed to attract all but the most intrepid travellers. The planned road might make it easier to bring in supplies but for how long? 
The answer to this question came in 1993, when I was engaged as an AusAID-funded consultant to the Royal Papua New Guinea Constabulary, working with women police and police-community relations. The trip had begun awkwardly when I spoke at the Mendi police station about the police commissioner's policy on domestic violence. The officer-in-charge clearly did not agree with any official attempts to modify his off-duty behaviour and it was a relief for my counterpart and myself to be able to travel to Tari the next morning, where we anticipated (and received) a much more positive and friendly reception.

Our driver and the armed police guards who accompanied us were happy to talk about the pressures and tensions they were increasingly experiencing since the gas pipeline had progressed, and the road to Kutubu had been opened up. As we passed the access road to our former walking track they remarked that armed holdups and confrontations were now commonplace. There had been an upsurge in tribal fighting in some areas and houses had recently been burnt down in a nearby village. In addition, there had been an increase in the operation of young raskol groups who wanted to get their share of the action. Closer to Lake Kutubu, demands for large compensation payments after inter-group fights were now the norm, and conflicts over anticipated royalties had increased (see Sagir 2001 for a discussion of conflicts in 1993/94 between the Fasu and Foi landowners, and between landowners and Chevron officials).

Demands were now frequently made for the police to take control and restore law and order. Life was clearly very fraught for these symbols of state authority and control, and I was reminded of that earlier patrol that had blundered onto the fight ground. Reports of police encounters with community groups and raskol gangs would vary widely, and all sides would feel that they were caught up in a situation that had somehow got 'out of control'.

\section{Conclusion: Whose kind of development do they want?}

Reflecting back on the development discussions I have shared since 1972, it seems as if nothing has really changed. Southern Highlanders were wary when the first patrol crossed onto their fight ground more than forty years ago. They had every right to be cautious, as since then most externally-planned large economic activities have mainly benefited the outsider while others have remained unaffected. Even where smaller, more manageable and socially acceptable, economic projects have been introduced, policy and implementation guidelines have already been approved, without their knowledge or input. It is usually only when the economic or social development 'patrols' arrive that they are really aware of what is happening. At this stage, it is too late to change the course of the project, so wary acceptance and manipulation to gain the greatest possible advantage may be the only possible response. 
In recent years, it has been suggested that lessons have been learned from earlier mistakes, and that foreign investors and aid project managers are more sensitive to the importance of working with local stakeholders. Chevron's community development approach is cited by some observers as being the way forward, an approach that minimises conflict and resolves disputes before they threaten to seriously compromise the whole project. Others (for example, Brunton 1992; Kennedy 1996) see these initiatives as continuing, albeit under a more acceptable guise, the cycle of external manipulation and control. From their perspective, this does not address the fundamental differences between what the people want, and what outsiders consider is good for them, or stand to gain by using this 'softly, softly' approach.

But another, and perhaps more hopeful, conclusion is that Southern Highlanders have themselves become more adept and confident in their ability to benefit from the numerous economic initiatives to which they have been exposed. Describing his first encounter in 1980 with the complexities of cultural change, the late anthropologist Jeffrey Clarke recalled how he had been driven to Takuru in the Pangia District 'in a Toyota belonging to the Southern Highlands Rural Development Project (SHRDP) funded by the World Bank'. Revisiting the Wiru in 1992, he found that a type of 'cultural revival' was taking place but considered that this was really a way of seeking the economic tourist advantages of traditional culture (Clarke 2000: Preface). He concluded (ibid: 172) that:

The cultural 'revival' was a quest to regain the lost autonomy denied by colonialism, and to withdraw to some extent from the control of the state.

Southern Highlanders may not wish to completely withdraw from the control of the state, and certainly not from the economic opportunities that foreign investment sanctioned by the state offers. Yet they remain ambivalent towards 'our kind of development'. In these circumstances, some conflict is inevitable and understandable, as it is an integral part of their ongoing quest to regain cultural autonomy and a sense of their own identity and place in the modern world.

\section{References}

Bais, T., et al. 1973 'Wambip community study'. Report of a student field trip to the Southern Highlands. University of Papua New Guinea, typescript.

Bourke, R. M., Allen, B. J., Hide, R. L, Fritsch, D., Grau, R., Hobshawn, P., Konabe, B., Levell, M.P., Lyon, S., and Varvaliu, A. 1995 'Southern Highlands Province, Text Summaries, Maps, Code Lists and Village Identification'. Agricultural Systems of Papua New Guinea, Working Paper No.11, Canberra: Department of Human Geography, The Australian National University. 
Brunton, B. 1992 'The Struggle for the Oil Pipeline in Papua New Guinea'. Discussion Paper Number 68. Boroko: National Research Institute.

Clark, J. 2000 Steel to Stone: A Chronicle of Colonialism in the Southern Highlands of Papua New Guinea. Oxford: Oxford University Press.

Conyers, D., 1976. The Provincial Government Debate. Boroko: Institute of Applied Social and Economic Research, Monograph 2.

French, W. and Walter, M. A. H. B. 1984 'Background to the Southern Highlands Province', in W. French and M. A. H. B. Walter (eds), What Worth Evaluation? Experiences with a World-Bank Aided Integrated Rural Development Project in the Southern Highlands Province of Papua New Guinea. Boroko: Institute of Applied Social and Economic Research, Monograph 24, pp. 15-26.

Hinchliffe, K., with Ilave, H. 1984 'Project organisation and management', in W. French and M. A. H. B. Walter (eds), What Worth Evaluation? Experiences with a World-Bank Aided Integrated Rural Development Project in the Southern Highlands Province of Papua New Guinea. Boroko: Institute of Applied Social and Economic Research, Monograph 24, pp. 27-68.

Kennedy, D. 1996 'Development or sustainability at Kutubu, Papua New Guinea?' in Richard Howitt, with John Connell and Philip Hirsch (eds), Resources, Nations and Indigenous Peoples, Case Studies from Australasia, Melanesia and Southeast Asia. Melbourne: Oxford University Press, pp.236-250.

Kombeson, B. 1983 'Umbimi Pentacostal Youth Group'. Student fieldwork report, typescript.

May, R. J., Regan, A. J. and Ley, A. (eds) 1997 Political Decentralisation in a New State. The Experience of Provincial Government in Papua New Guinea. Bathurst: Crawford House Publishing.

McAlpine, J. 1972 'Southern Highlands District', in P. Ryan (ed.), Encyclopaedia of Papua New Guinea. Melbourne: Melbourne University Press (in association with University of Papua New Guinea), pp. 1085-1091.

O'Collins, M. 1984 Youth in Papua New Guinea: With Reference to Fiji, Solomon Islands and Vanuatu. Political and Social Change Monograph 3. Canberra: Research School of Pacific Studies, The Australian National University.

O'Connell, C. and Zarriga, R.I. 1991 'Papua New Guinea's National Youth Movement', in Sandra Sewell and Anthony Kelly (eds), Social Problems in the Asia Pacific Region. Brisbane: Boolarong Publications, pp. 210243.

Office of Youth, Women, Religion and Recreation 1983 'Second NYMP Grants Scheme Implementation Report'. Port Moresby, mimeographed. 
Regan, A. J. 1997 'The origins of the provincial government system in Papua New Guinea', in R.J. May and A.J. Regan with A. Ley (eds), Political Decentralisation in a New State. The Experience of Provincial Government in Papua New Guinea. Bathurst: Crawford House Publishing, pp. 9-20.

Sagir, B. F. 2001 'The politics of petroleum extraction and royalty distribution at Lake Kutubu', in A. Rumsey and J. Weiner (eds), Mining and Indigenous Lifeworlds in Australia and Papua New Guinea. Adelaide: Crawford House Publishing, pp. 145-156.

World Bank. 1978 Papua New Guinea, its Economic Situation and Prospects for Development. Washington DC: The World Bank. 